\title{
Pengarusutamaan Moderasi Beragama; Strategi Tantangan dan Peluang FKUB Jawa Timur
}

\author{
M. Thoriqul Huda \\ Institut Agama Islam Negeri Kediri, Indonesia \\ huda@iainkediri.ac,id
}

\begin{abstract}
Religious moderation is one of the means to strengthen and strengthen a harmonious, safe and peaceful religious life. Indonesia is a country with multiple religions, ethnicities and races, so the adherence to religious moderation in the life of the nation and state is an obligation. The study in this paper is one of the efforts to further examine the efforts and strategies of the East Java Religious Harmony Forum (FKUB) in grounding the attitude of religious moderation in its region, in this study researcher used interview and observation techniques at the East Java Religious Harmony Forum. The results of this research are that there are several strategies carried out by FKUB in an effort to ground religious moderation, including holding discussions on religious moderation, creating a guidebook on religious moderation, strengthening the insight into religious moderation for the millennial generation, and strengthening cooperation with other parties related to religious moderation. Religious moderation program. Furthermore, there are several challenges in grounding religious moderation, including the increasing religious orthodoxy and conservatism, the strengthening of the issue of identity politics, and the era of social media. In addition, the culture of the East Java people who are friendly, polite and tolerant between individuals is one of the strengths and assets for FKUB to continue to ground religious moderation in society.
\end{abstract}

Keywords; Strategy, Religious Moderation, FKUB

\begin{abstract}
Abstrak
Moderasi beragama merupakan salah satu upaya untuk meneguhkan dan mengokohkan kehidupan beragama yang rukun, aman dan damai. Indonesia merupakan Negara dengan multi agama, suku, dan ras, sehingga pengauatan moderasi beragama dalam kehidupan berbangsa dan bernegara menjadi suatu kewajiban. Kajian dalam tulisan ini merupakan salah satu upaya untuk menelaah lebih lanjut tentang upaya dan strategi Forum Kerukunan Umat Beragama (FKUB) Jawa Timur dalam membumikan sikap moderasi beragama di wilayahnya, dalam penelitian ini peneliti menggunakan teknik wawancara dan observasi pada lembaga Forum Kerukunan Umat Beragama Jawa Timur. Adapun hasil dari penelitian ini adalah terdapat beberapa strategi yang dilakukan FKUB dalam upaya membumikan moderasi beragama, diantaranya adalah dengan menyelenggarakan diskusi tentang moderasi beragama, membuat buku pedoman moderasi beragama, memperkuat wawasan moderasi beragama bagi generasi milenial, serta memperkuat kerjasama dengan pihak lain yang terkait denga program moderasi beragama. Selanjutnya terdapat beberapa tantangan dalam membumikan moderasi beragama, diantaranya semakin naiknya ortodoksi dan konservatisme keagamaan, menguatnya isu politik identitas, serta era media sosial. Selain itu budaya masyarakat Jawa Timur yang ramah, sopan dan tenggangrasa antar individu menjadi salah satu kekuatan dan modal bagi FKUB untuk terus membumikan moderasi beragama di masyarakat.
\end{abstract}

Kata Kunci; Strategi, Moderasi Beragama, FKUB. 


\section{Pendahuluan}

Indonesia adalah sebuah Negara besar dalam pengertian yang sesungguhnya. Negara dengan jumlah penduduk 270 juta jiwa ini (sensus penduduk 2019), terdiri dari lebih 34 provinsi, 17.000 lebih gugus pulau besar dan kecil, ${ }^{1} 300$ kelompok etnik, ${ }^{2} 1.340$ suku bangsa, ${ }^{3} 718$ bahasa daerah, ${ }^{4} 6$ agama resmi dan ratusan agama lokal serta aliran kepercayaan lainnya. ${ }^{5}$ Sebanyak 87 persen dari total penduduk Indonesia menganut agama Islam (235 juta, terbesar di dunia), sementara sisanya adalah penganut Protestan (7,6 persen), Katolik (3,13 persen), Hindu (1,74 persen), Budha (0,77 persen), Konghucu $(0,03$ persen $)$, dan agama lainnya $(0,04$ persen $){ }^{6}$

Dengan fakta demografis dan geografis di atas, kita jadi tahu bahwa mengelola Indonesia pasti tidaklah mudah. Bayangan kerumitan dan keruwetan mengelola Indonesia begitu gamblang ketika kita membayangkan mengurusi seluruh negara di benua Eropa, atau seluruh negara di Timur Tengah dan Asia. Padahal benua Eropa hanya terdiri dari satu-dua suku bangsa, namun dipikul oleh banyak negara. Demikian juga Timur Tengah yang terdiri dari satu suku bangsa (Arab), tetapi dipikul oleh banyak negara. Indonesia adalah sebaliknya: satu negara memikul ribuan suku bangsa. Benarbenar sebuah keajaiban yang menakjubkan.

Dengan tingkat kompleksitas yang ada, mengurusi Indonesia jelas membutuhkan energi lebih. Jika salah urus, kemajemukan Indonesia dapat menjadi bencana ketimbang berkah. Salah urus kemajemukan yang berujung pada hancurnya sebuah negara bukanlah omong kosong belaka. Yugoslavia dan Uni Soviet menjadi contoh mutakhir negara yang tidak mampu mengelola kemajemukan kepentingan penduduknya, hingga akhirnya dua negara ini hancur berkeping-keping menjadi negara-negara kecil. ${ }^{7}$

Program penguatan sikap moderasi beragama merupakan salah satu upaya pemerintah dalam meminimalisir terjadinya konflik atau gesekan antar umat beragama,

\footnotetext{
${ }^{1}$ Widianingsih, "Demokrasi dan Pemilu di Indonesia: Suatu Tinjauan dari Aspek Sejarah dan Sosiologi Politik,” Jurnal Signal 5, no. 2 (2017): 1-19.

${ }^{2}$ Masrun Mooduto, "Identitas Etnik Keturunan Pengawal Imam Bonjol di Desa Lotta Kabupaten Minahasa," 2016, 1-9.

${ }^{3}$ Mohammad Mulyadi, "Membangun NKRI dengan Multikulturalisme," t.t., 9-12.

${ }^{4}$ Wiya Suktiningsih dan Hilda Hastuti, "Situasi Diglosia Pada Penutur Bahasa Bali di Kota Mataram Nusa Tenggara Barat" 6, no. 1 (2019): 18.

5 Ahmad Muttaqien, "Spritualitas Agama Lokal (Studi Ajaran Sunda Wiwitan aliran Madrais di Cigugur Kuningan Jawabarat)," t.t., 14.

${ }^{6}$ M Thoriqul Huda, "Strategi, Peluang dan Tantangan Membangun Kerukunan Pemuda Di Era Milenial," Satya Widya 3, no. 2 (2020): 98-114.

${ }^{7}$ Asrul Muslim, "Interaksi Sosial dalam Masyarakat Multiatnis," Jurnal Diskursus Islam 1, no. 3 (2013): 484-94.
} 
dengan memiliki kesadaran moderat dalam beragama maka pemeluk agama akan terhindar dari pemahaman keagamaan yang ekstrim, atau liberal. Membangun sikap moderasi beragam bagi pemeluk agama menjadi program prioritas pemerintah dalam mengukuhkan kerukunan beragama serta memperkuat karakter bangsa. Forum Kerukunan Umat Beragama (FKUB) sebagai salah satu lembaga yang forkus terhadap pembinaan kerukunan beragama di Indonesia memiliki tanggungjawab yang besar dalam membumikan sikap moderasi beragama sebagai salah satu bagian dari program rencana jangka menengan nasional (RPJMN).

FKUB Provinsi Jawa Timur merupakan salah satu lembaga yang bergerak pada penguatan kerukunan antar umat beragama di Jawa Timur, serta bertanggungjawab terhadap pemberian rekomendasi pelaksanaan pendirian rumah ibadah. FKUB di Jawa Timur terdapat pada masing-masing kabupaten/ Kota di Jawa Timur, anggota pengurusnya terdiri dari masing-masing elemen perwakilan majelis tinggi agama-agama, seperti MUI, MATAKIN, Walubi, PHDI, PGI, serta Katolik.

Provinsi Jawa Timur memiliki komposisi mayoritas penduduk beragama Islam 95,53\%, diikuti Kristen-Protestan 2,20\%, Katholik 1,32\%, Hindu 0,60\%, Budha 0,34\%, Konghucu $0,01 \%$, dan lainnya $0,01 \%{ }^{8}$ Secara sosio-budaya dapat dikelompokkan menjadi delapan wilayah kebudayaan (tlatah) dengan ciri masing-masing/ yaitu Jawa Mataram, Jawa Panaragan, Arek, Samin, Tengger, Osing, Pandalungan, Madura Pulau, Madura Bawean, Madura Kangean. ${ }^{9}$

Melihat kondisi Jawa Timur yang majemuk, maka sikap moderat dalam beragama menjadi keharusan untuk terus dibumikan dalam jiwa pemeluk agama, hal ini untuk menghindari terpaparnya paham radikal datau liberal pada sikap keagamaan pemeluk agama di Jawa Timur. FKUB Jawa Timur sebagai salah satu lembaga yang membidangi kerukunan beragama, memiliki tanggungjawab terhadap pembuman sikap moderasi beragama bagi pemeluk agama di Jawa Timur. Dalam kajian historis, konflik horizontal keagamaan yang melibatkan unsur masyarakat beragama pernah terjadi di Jawa Timur, sebut saja konflik Syiah-Sunni di Sampang pada tahun 2012, ${ }^{10}$ serta pelarang aktifitas jemaat ahmadiyah oleh Gubernur Jawa Timur tahun 2011 yang sempat memicu

\footnotetext{
8 "Provinsi Jawa Timur Dalam Angka," 2012, 74.

${ }^{9}$ Ayu Sutanto dan Setya Yowono Sudikan, Pendekatan Kebudayaan dalam Pembangunan Provinsi Jawa Timur, 2004.

${ }^{10}$ Rachmah Ida dan Laurentius Dyson, "Konflik Sunni-Syiah dan dampaknya terhadap komunikasi intra-religius pada komunitas di Sampang-Madura," Masyarakat, Kebudayaan dan Politik 28, no. 1 (1 Januari 2015): 33-49, https://doi.org/10.20473/mkp.V28I12015.

Tribakti: Jurnal Pemikiran Keislaman

Volume 32, Nomor 1, Juli 2021
} 
kegelisahan bagi Jemaat Ahmadiyah di Jawa Timur dalam beraktifitas sosial keagamaan. ${ }^{11}$

Sedangkan kajian terkait dengan moderasi beragama sendiri sudah pernah dilakukan beberapa kali oleh akademisi dan peneliti, diantaranya adalah penelitian Mohamad Fahri dengan judul moderasi beragama di Indonesia, ${ }^{12}$ penelitian Ali Nurdin yang berjudul model moderasi beragama berbasis pesantren salaf, ${ }^{13}$ kajian moderasi beragama yang dilakukan oleh Wildan Hefni (IAIN Jember) berjudul moderasi beragama dalam ruang digital; studi pengarusutamaan moderasi beragama di Perguruan Tinggi Keagamaan Islam Negeri. ${ }^{14}$ Dari telaah kajian penelitian terdahulu berkaitan dengan moderasi beragama, dapat dilihat bersama bahwa kajian yang dilakukan oleh peneliti saat ini lebih menfokuskan pada peran FKUB sebagai organisasi keagamaan dalam membangun sikap dan wawasan moderat, hal ini berbeda dengan kajian terdahulu berkaitan dengan moderasi beragama.

Untuk melihat lebih dalam tentang peran FKUB dalam membentuk sikap moderat, maka ada beberapa persoalan yang akan diangkat seperti bagaimana strategi FKUB dalam membangun wawasan moderat bagi pemeluk agama di Jawa Timur, sedangkan tujuan dalam kajian ini adalah untuk melihat lebih dalam strategi, tantangan dan peluang FKUB dalam membangun wawasan moderat bagi pemeluk agama di Jawa Timur. Lebih lanjut penelitian ini diharapkan dapat menjadi rujukan bagi FKUB di kabupaten kota se Jawa Timur untuk terus mengembangkan wawasan moderat di daearah agar tercipta kondisi keberagamaan yang harmonis.

Dalam Islam dikenal adanya istilah wasth, wasathiyah, wasith, yang artinya penengah, ${ }^{15}$ di tengah-tengah atau pertengahan. Dalam Al-Qur'an dijelaskan bahwa: "Dan demikian pula Kami telah menjadikan kamu "ummat pertengahan" agar kamu menjadi saksi atas (perbuatan) manusia dan agar Rasul (Muhammad) menjadi saksi atas (perbuatan) kamu" (QS. 2: 143). Selain itu, dalam ayat yang lain Allah menegaskan

\footnotetext{
11 Ach. Faid Haris dan Marwini, "Pelarangan Aktifitas Jamaat Ahmadiyah Indonesia Prespektif Hukum dan HAM ((Mengkaji Legalitas Sk Gubernur Jawa Timur Nomor 188/94/Kpts/013/2011)," Al Mazahib; Jurnal Pemikiran Hukum 1, no. 2 (2012): 325-45.

12 Mohamad Fahri, "Moderasi Beragama di Indonesia," INTIZAR 25, no. 2 (2019): 95-100.

13 Ali Nurdin, "Model Moderasi Beragama Berbasis Pesantren Salaf," ISLAMICA; Jurnal Studi Keislaman 14, no. 1 (2019): 82-102.

${ }^{14}$ Wildan Hefni, "Studi Pengarusutamaan Moderasi Beragama di Perguruan Tinggi Keagamaan Islam Negeri," Jurnal BIMAS Islam 13, no. 1 (2020): 1-22.

15 Komaruddin Hidayat, Agama untuk Peradaban: Membumikan Etos Agama dalam Kehidupan (Komaruddin Hidayat: Alvabet, 2019), 64-67.
} 
bahwa Islam adalah agama rahmat bagi seluruh alam (wa ma arsalnaka illa rahmatan lil alamin) (QS Al-Anbiya': 107). Dalam sebuah Hadis Nabi dijelaskan: “sebaik-baik persoalan adalah yang ada di tengah" (khayr al-umur awsatuha). ${ }^{16}$

Menurut KBBI terma "moderat" memiliki dua makna, yaitu: (1) selalu menghindarkan perilaku atau pengungkapan yang ekstrem; dan (2) berkecenderungan ke arah dimensi atau jalan tengah. ${ }^{17}$

Dalam kamus The American Heritage Dictionary of the English Language mendefinisikan moderate sebagai: not excessive or extreme (tidak berlebihan dalam hal tertentu). ${ }^{18}$ Sedangkan Kementerian Agama RI mendefinisikan moderasi beragama sebagai “cara pandang, sikap, perilaku selalu mengambil posisi di tengah-tengah, selalu bertindak adil, dan tidak ekstrem dalam beragama,"19 Namun demikian, cara pandang seperti ini justru sering dikritik oleh sejumlah kalangan sebagai sikap keberagamaan yang tidak jelas, ambigu, dan tidak menemukan pijakan teologis yang tegas. Posisi ambigu semacam ini dianggap sama dengan konsep "la-wa-la" (bukan-dan-bukan), sebuah istilah yang merujuk pada posisi yang tidak ke mana-mana: bukan Barat atau Timur, bukan ekstrem kiri atau ekstrem kanan, bukan literalis atau liberalis, bukan ini dan bukan itu, dan seterusnya. ${ }^{20}$ Dalam benak para pengeritik, posisi semacam ini merepresentasikan Islam yang tidak autentik, Islam yang terdegradasi. Menurut mereka, Islam tidak mengenal atribusi, kata sifat atau karakteristik lain di luar kata Islam: Islam ya Islam, tidak ada embel-embel moderat atau semacamnya. Islam hanya ada satu, yakni Islam yang tidak menerima kata sifat apapun.

Ahmad Najib Burhani memaknai Islam moderat untuk Indonesia lebih pada makna bahasanya, yaitu sebagai "mid-position between liberalism and Islamism". Orang atau organisasi yang berada di tengah-tengah antara liberalisme dan Islamisme adalah moderat. $^{21}$

16 Ahmad Subakir dan Ahmad Khoirul Mustamir, "Gerakan Moderasi Islam dalam Prespektif Deteksi Dini; Studi Gerakan Pemuda Ansor Kota Kediri," Tribakti; Jurnal Pemikiran Islam 31, no. 2 (2020): 187-201.

${ }^{17}$ Pusat Bahasa Departemen Pendidikan Nasional, Kamus Bahasa Indonesia (Jakarta: Pusat Bahasa, 2008), 964.

${ }^{18}$ Miftahuddin, "Islam Moderat dalam Konteks Indonesia dalam Prespektif Historis," Jurnal Mozaik V, no. 1 (2010): 41-54.

${ }^{19}$ Kemenag RI, Moderasi Beragama (Kementerian Agama, 2019), 17.

20 Masdar Hilmy, "Whiter Indonesia's Islamic Moderatism,? A Reexamination on the moderate Vision of Muhammadiyahand NU," 71 (2013): 25-48.

21 Ahmad Najib Burhani, "Pluralism, Liberalism and Islamism: Religious Outlook of the Muhammadiyah Islamic Movement in Indonesia, M.A" (Faculty of Humanities, University of Manchster, 2007), 7.

Tribakti: Jurnal Pemikiran Keislaman Volume 32, Nomor 1, Juli 2021 
Di luar kelompok moderat, terdapat dua kutub ekstrem yang dalam Terminologi keagamaan disebut sebagai mutatharrifun atau kelompok pinggir. ${ }^{22}$ Kelompok ini terdiri dari mereka yang memahami agama sebagai secara sempit, tertutup atau harafiyah. ${ }^{23}$ Kelompok ini dapat dijumpai pada mereka yang melebih-lebihkan amalan-amalan ibadah mereka sebagai sesuatu yang wajib atau fardlu dan haram. ${ }^{24}$ Tidak ada sesuatu yang masuk dalam kategori mubah, makruh atau sunnah. Misalnya hukum berjihad. Bagi mereka hukum jihad cuma satu: wajib atau fardlu 'ain. Tidak ada makruh, sunnah, mubah. Setiap fi'il amr (perintah) dalam ayat-ayat Al-Qur'an berimplikasi pada hukum wajib karena berisi perintah Allah.

Dalam konteks Indonesia, konsep moderasi Islam setidaknya harus mengandung beberapa elemen berikut ini; 1). Ideologi nirkekerasan dalam memahami dan menyebarluaskan Islam; 2). Pengadopsian cara hidup modern beserta segala derivasinya seperti sains dan teknologi, demokrasi, hak asasi manusia dan semacamnya; 3). Pengadopsian cara berpikir rasional; 4). Pendekatan kontekstual dalam memahami Islam, dan; 5). Penggunaan ijtihad dalam menyelesaikan berbagai persoalan kontemporer. ${ }^{25}$ Di luar lima karakteristik tersebut, barang kali terdapat beberapa karakteristik lain yang perlu dimasukkan sebagai ciri-ciri Islam moderat seperti toleransi, harmoni atau kerukunan dan Kerjasama di antara ummat beragama yang berbeda.

Dalam perspektif Kemenag RI (2019), ukuran-ukuran moderasi keagamaan adalah sebagai berikut: 1). Komitmen kebangsaan. Komitmen kebangsaan menjadi tolok ukur apakah seseorang terjatuh kedalam ideologi radikal atau moderat karena kebanyakan Gerakan radikal mengadopsi ideologi khilafah atau negara shari'ah. Konsep negara bangsa dianggap sebagai bid'ah, thagut dan kafir yang tidakberpijak pada ajaran Islam. 2). Toleransi. Toleransi menjadi sesuatu yang penting karena kebanyakan kelompok radikal tidak akan pernah menoleransi perbedaan tafsir keagamaan di kalangan ummat Islam. Begitu terdapat perbedaan tafsir keagamaan, maka kelompok yang berbeda akan

\footnotetext{
${ }^{22}$ Abu Bakar, "Theologi Fundamentalisme", TOLERANSI; Media Komunikasi Umat Beragama" 6, no. 2 (t.t.): 6 .

${ }^{23}$ Suryo Ediyono, "Coping with Fundamentalism in a Tolerant Country, International Journal of Multicultural and Multireligious Undertansding” 6, no. 1 (2019): 45-53.

${ }^{24}$ Farid Hasan, "Model Pembacaan Kontekstual Nasr Hamid Abu Zayd Terhadap Teks Suci Keagamaan (Al Qur'an)," Jurnal Ilmiah Citra Ilmu 16, no. 31 (2020): 11-22.

${ }^{25}$ Hilmy, "Whiter Indonesia's Islamic Moderatism,? A Reexamination on the moderate Vision of Muhammadiyahand NU," 25-48.
} 
dianggap sesat, kafir (takfir), murtadz dan semacamnya. 3). Anti-kekerasan. Kaum moderat selalu menggunakan cara-cara damai dalam melakukan transforma sisosialpolitik, bukan kekekerasan. 4). Akomodatif terhadap kebudayaan lokal. Jika kaum moderat mengakomodasi kebudayaan lokal, kelompok radikal menganggapnya sebagai bid'ah, syirik dan menyimpang dari ajaran Islam yang sesungguhnya.

Pada bulan Mei tahun 2006, terbitlah Peraturan Bersama Menteri (PBM) Agama dan Menteri Dalam Negeri Nomor 9 dan Nomor 8 tahun 2006 tentang pendoman Pelaksaan tugas Kepala Daerah/Wakil Kepala Daerah dalam pemeliharaan Kerukunan Umat Beragama, pemberdayaan Forum Kerukunan Umat Beragama dan Pendirian Rumah Ibadah. Peraturan Bersama Menteri ini sebagai revisi dan penyempurnaan atas Surat Keputusan Bersama Menteri Agama dan Menteri Dalam Negeri No. 01/1969. PBM antara pemerintah dengan Majelis-Majelis Agama dimulai sejak tanggal 28 Oktober 2005 sampai dengan 21 Maret 2006 dalam 11 (sebelas) kali putaran. Kemudian pada tanggal 22-24 Agustus 2006 di Jakarta, telah diadakan kongres Tokoh-Tokoh Agama se-Indonesia yang difasilitasi oleh Depertemen Agama dan dihadiri oleh Majelis-Majelis agama.

Untuk menyelaraskan dengan kebijakan pembinaan kerukunan umat beragama pemerintah pusat serta guna merealisasikan salah satu kebijakan tiga program prioritas Pemerintah Daerah Tingkat 1 Jawa Timur, khususnya di bidang Kehidupan Umat Beragama, maka pada sekitar tahun 1996, dibentuklah "Kelompok Kerja Pembinaan Kehidupan Umat Beragama (Pokja PKUB)", kemudian melalui Surat Keputusan Gubernur (Moh. Basori Sudirman) No 144 tahun 1996, tanggal 23 September 1996, susunan pengurusnya mengalami penyempurnaan yang diketuai H.A Latief Burhan dan Melibatkan semua unsur agama (Islam, Katholik, Kristen, Hindu dan Budha). ${ }^{26}$

Adapun tugas pokok Pokja PKUB Antara lain:

a. Membantu (termasuk memberikan saran dan masukan dalam penyusunan program serta menyampaikan laporan perkembangan periodik) kepada Gubenur yang berkaitan dengan pembinaan KUB.

b. Melakukan konsultasi dan koordinasi serta menampung Sran/ masukan dari lembaga dan organisasi sosial keagamaan maupun perorangan dari pemuda dari pemuka agama / tokoh masyarakat, mengenai pembinaan KUAB.

\footnotetext{
${ }^{26}$ Forum Kerukunan Umat Beragama Provinsi Jawa Timur, Sewindu (Surabaya: FKUB JATIM,
} 2014). 
Selanjutnya kelompok kerja PKUB melakukan sosialisasi dengan melaksanakan kunjungan kerja serta dialog ke berbagai daerah, guna menyerap aspirasi masyarakat bawah untuk menyusun pedoman pembinaan kerukunan umat beragama. Hal ini dilakukan agar pelaksanaan pembinaan kerukunan umat beragama dapat berjalan bersinenrgi dengan daerah, berjalan searah dalam datu roadmap yang sudah disepakati, serta sejalan dengan program pembangunan provinsi yakni terejawantahkannya nilainilai beragama dalam kehidupan bermasyarakat, berbangsa dan bernegara.

Berdasarkan kajian terbatas (sekitar tahun 1999) dari unsur-unsur Biro Mental spiritual Pemerintah Provinsi, kantor wilayah Depertemen Agama dan IAIN Sunan Ampel dengan masukan dari Ormas Keagamaan Islam dan Majelis agama berdasarkan Surat Keputusan Gubenur Jawa Timur (H. Imam Utomo) No. 451/1178/031/2000, tanggal 10 Pebruari 2000 tentang Pembinaan KHUB dan SK Gubenur No 188/106/KPTS/2002, tanggal 18 April 2002 tentang Pembentukan FKAUB Provinsi Jawa Timur.

Menindaklanjuti dan menyesuaikan dengan PMB No.9 dan 8 tahun 2006, Gubenur Jawa Timur telah menerbitkan:

a. Peraturan Gubenur Jawa Timur No 1 Tahun 2007 tanggal 11 Januari 2007 tentang FKUB dan DP-FKUB provinsi dan Kab / kota di Jawa Timur (sebagai pelaksanaan pasal $27 \mathrm{PBM}$ ). ${ }^{27}$

b. Keputusan Gubenur Jawa Timur No.188/57/KPTS/013/2011, tanggal Pebruari 2007, tentang FKUB Provinsi Jawa Timur dan No. 188/58/KPTS/013/2007 tenteng DP-FKUB Provinsi Jawa Timur.

Berdasarkan Peraturan Gubernur Jawa Timur No.1 Tahun 2007 maka dibentuklah:

a. FKUB Provinsi Jawa Timur;

b. FKUB di 38 Kabupaten/ kota se Jawa Timur (yang seluruhnya selesai dalam tahun 2007);

Bahkan tahun 2012 telah terbentuk Forum Kerukunan Umat Beragama Antar Generasi Muda (FORKUGAMA), forum ini berada di bawah naungan FKUB Jawa Timur yang melibatkan pemuda generasi milenial dalam ikut serta berpartisipasi

\footnotetext{
27 “Keputusan Gubernur Jawa Timur Nomor 188/ 217 /KPTS/013/2015 tentang Forum Kerukunan Umat Beragama (FKUB) Provinsi Jawa Timur Tahun 2015," http://arsipjdih.jatimprov.go.id/upload/741/KEPGUB.NOMOR_217_.TAHUN_2015_.TENTANG_FOR UM_KERUKUNAN_UMAT_BERAGAMA_PROVINSI_JAWA_TIMUR_TAHUN_2015_.pdf, t.t.
} 
membangun kerukunan umat beragama di Jawa Timur khususnya bidang pemuda. ${ }^{28}$ Selanjutnya pada tahun 2020 mulai dirintis wanita lintas iman, dimana forum ini menaungi wanita-wanita lintas agama, berada di bawha FKUB Jawa Timur, forum ini menfokuskan diri pada isu-isu wanita dalam kajian lintas agama. Semakin bertambah usia Forum Kerukunan Umat Beragama Provinsi Jawa Timur, maka semakin besar pula tanggungjawab yang diemban, sehingga diperlukan pembentukan forum-forum sayap di bawah naungan FKUB.

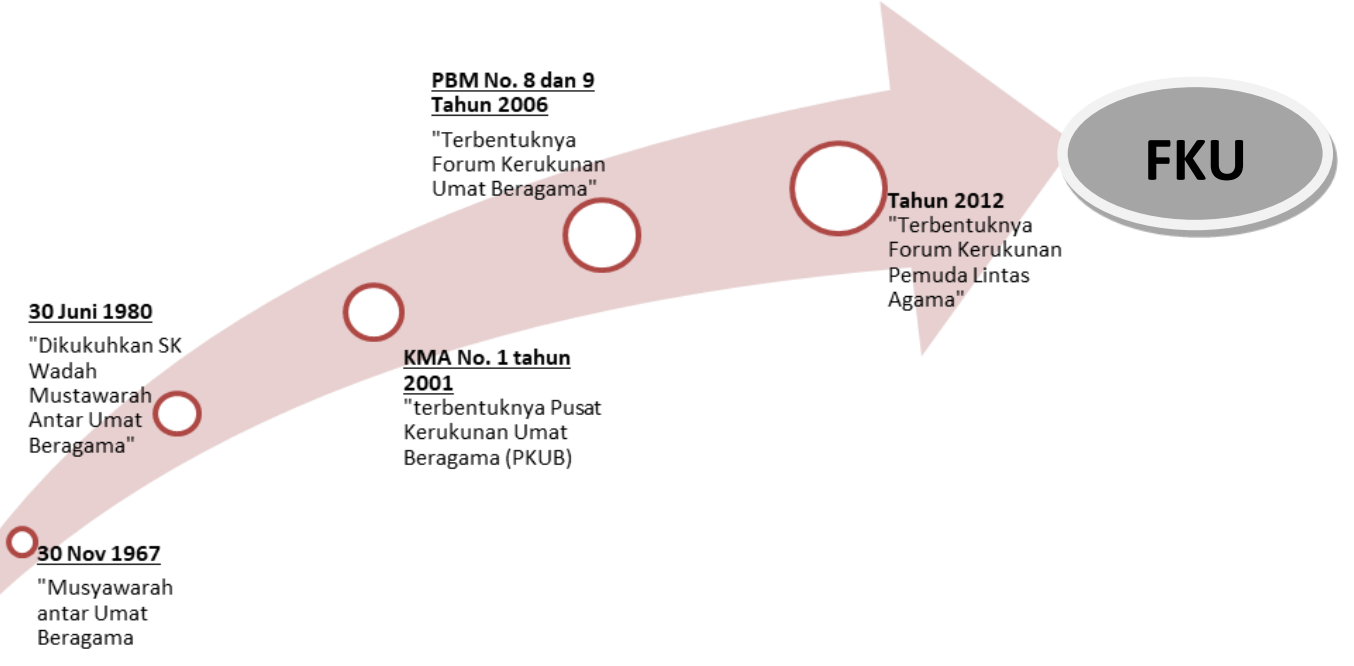

\section{Metode}

Naskah ini merupakan hasil penelitian lapangan dengan menggunakan pendekatan kualitatif, pendekatan ini sering disebut juga dengan pendekatan naturalistik ${ }^{29}$, hal ini dikarenakan penelitiannya dilakukan pada kondisi yang alamiah. Dalam melakukan penggalian data penelitian menggunakan teknik wawancara ${ }^{30}$, observasi $^{31}$ dan dokumentasi ${ }^{32}$. Wawancara adalah suatu metode yang digunakan untuk mendapatkan data di lapangan dengan cara melakukan tatap muka, bercakap- cakap secara langsung dengan responden di lapangan dalam hal ini adalah pengurus Forum Kerukunan Umat Beragama (FKUB) Jawa Timur, teknik ini dilakukan untuk mendapatkan data terkait dengan program FKUB dalam memperkuat wawasan moderasi beragama pada masyarakat lintas agama di Jawa Timur. Sedangkan observasi dilakukan sebagai upaya

\footnotetext{
${ }^{28}$ Forum Kerukunan Umat Beragama Provinsi Jawa Timur, Sewindu.

${ }^{29}$ Sugiyono, Metode Penelitian Kuantitatif Kualitatif R\&D (Bandung : ALFABETA, 2012), 8

${ }^{30}$ Black James, Metode dan Masalah Penelitian Sosial, (Jakarta :Refika Aditama, 1999), 285

${ }^{31}$ S. Margono, Metodologi Penelitian Pendidikan, (Jakarta: PT. Rineka Cipta, 1997), 158. ${ }^{32}$ Ibid, 216-217.
}

Tribakti: Jurnal Pemikiran Keislaman Volume 32, Nomor 1, Juli 2021 
melakukan pengamatan di lapangan pada objek penelitian yakni Forum Kerukunan Umat Beragama (FKUB) secara kelembagaan, dan teknik dokumentasi dilakukan secara mendalam guna mendapatkan data yang lebih real terkait dengan sejarah FKUB serta beragam kegiatan FKUB yang berkaitan dengan pengarusutamaan moderasi beragama serta upaya menjaga kerukunan umat beragama di Jawa Timur.

\section{Hasil dan Pembahasan}

Melihat realitas kemajemukan bangsa Indonesia yang terdiri dari berbagai latar belakang yang berbeda, maka moderasi beragama menjadi ujung tombak yang mendasari kerukunan umat beragama di masyarakat. FKUB sebagai salah satu lembaga keagamaan yang konsen terhadap pembangunan kerukunan umat beragama menyambut baik upaya pemerintah dalam membumikan sikap moderasi beragama bagi pemeluk agama di Indonesia, FKUB telah menyiapkan langkah-langkah strategis dalam upaya membumikan moderasi beragama di Jawa Timur, diantaranya;

Pertama, menyelenggarakan diskusi moderasi beragama bagi ketua mejelis agama-agama. Seminggu setelah ketua Pusat Kerukunan Umat Beragama Republik Indonesia berkunjung ke FKUB Jawa Timur dan menyelenggarakan diskusi dengan tema moderasi beragama, FKUB Jawa Timur melanjutkan rekomendasi kegiatan dengan melakukan diskusi moderasi beragama dalam prespektif majelis agama-agama, dalam pertemuan semiloka yang diselenggarakan di Malang tersebut menghasilkan titik temu landasan teologis agama-agama berkaitan dengan moderasi beragama, pada dasarnya semua agama memliki konsep moderasi, bahkan secara teologis dan epistemologis kerangka moderasi beragama dapat disampaikan dengan baik oleh masing-masing perwakilan majelis tinggi agama-agama, seperti MUI, Walubi, PHDI, Matakin, PGI dan Katolik. $^{33}$

Kedua, menyusun buku pedoman moderasi beragama. Berbagai lembaga keagamaan yang konsen terhadap pembinaan kerukunan umat beragama saat ini telah mencurahkan semua tenaga yang dimilikinya untuk terus menggaungkan dan membumikan sikap moderasi beragama, salah satu upaya yang dilakukan adalah melalui penerbitan buku pedoman moderasi beragama, sekalipun sudah banyak buku berkaitan dengan moderasi beragama, baik yang ditulis akademisi ataupun pihak lain diterbitkan

${ }^{33}$ Hamid Syarif, Wawancara dengan Ketua FKUB Jawa Timur, t.t. 
dalam kurun waktu beberapa tahun terahir ini. FKUB Jawa Timur mencanangkan pembuatan buku pedoman moderasi beragama berdasarkan dengan kondisi dan kenyataannya di lapangan di provinsi Jawa Timur, hal ini untuk menggambarkan bahwa Jawa Timur memiliki kerangka sikap-sikap moderasi beragama yang perlu dipedomani, sehingga dapat dijadikan contoh bersama untuk pengembangan sikap moderasi beragama di wilayah lain. ${ }^{34}$

Ketiga, sekolah moderasi beragama bagi generasi milenial. Tahun 2020, jumlah generasi $\mathrm{Z}$ di Indonensia mencapai $27,94 \%$ atau 75,49 juta jiwa, sedangkan jumlah generasi milenial mencapai $25,87 \%$ atau 69,90 juta jiwa dari total jumlah penduduk Indonesia yang mencapai 270 juta jiwa. Salah urus dalam membangun karakter generasi penerus dapat menjadikan bangsa ini terjerumus dalam kehancuran. Membumikan sikap moderasi beragama bagi generasi milenial merupakan salah satu uapaya membangun sikap sadar kemajemukan bangsa, sehingga generasi penerus bangsa terhindar dari sikap intoleran, radikal dan ekstrim.

Keempat, memperkuat kerjasama dengan berbagai pihak, membangun kerukunan beragama tidak dapat dilakukan sendiri, perlu melibatkan semua pihak dalam upaya bersama untuk terus bersinergi dalam membumikan sikap moderasi beragama sebagai landasan dalam membangun kehidupan yang rukun dan damai. Seperti yang kita ketahui saat ini melalui Surat Keputusan Direktur Jendral Pendidikan Islam Nomor 897 Tahun 2021 tentang Petunjuk Teknis Rumah Moderasi Beragama di lingkungan Pendidikan Tinggi Keagamaan Islam, ${ }^{35}$ Kementerian Agama membentuk Rumah Moderasi Beragama di masing-masing PTKIN untuk terus membumikan moderasi beragama di perguruan tinggi, sedangkan secara luas pada masing-masing lembaga pemerintahan, rumah moderasi beragama mulai dibentuk berdasarkan pada RPJMN 2020-2024. ${ }^{36}$

Sedangkan dalam membumikan moderasi beragama, terdapat beberapa tantangan yang dihadapi oleh, diantaranya adalah; (1), Naiknya ortodoksi dan konservatisme keagamaan, ${ }^{37}$ Tantangan yang pertama berasal dari kaum mutatharrifun, kelompok garis keras yang memahami agama dari sudut pandang yang sempit, harafiyah

\footnotetext{
34 Tamhid Masyhudi, Wawancara dengan Sekertaris FKUB, t.t.

35 Direktur Jenderal Pendidikan Islam, "Keputusan Direktur Jenderal Pendidikan Islam Nomor 897 Tahun 2021 tentang Petunjuk Teknis Rumah Moderasi Beragama," http://diktis.kemenag.go.id/v1/public/files/ec92fa8e02bc0f378c961ae572990875.Edaran\%20Juknis\%20R umah\%20Moderasi\%20Beragama\%20(12\%20Maret\%202021).pdf, t.t.

${ }^{36}$ Dedy Ardianto, Wawancara dengan Pemuda FKUB, t.t.

37 "Majalah FORUM Forum Kerukunan Umat Beragama Jawa Timur," 2021.
}

Tribakti: Jurnal Pemikiran Keislaman

Volume 32, Nomor 1, Juli 2021 
dan tertutup. Secara umum kaum mutatharrifun terbagi kedalam dua kategori; kategori pro-kekerasan dan kategori nirkekerasan. Mereka yang masuk dalam kelompok mutatharrifun pro-kekerasan adalah kelompok jihadis yang hanya memiliki satu metode dakwah, yakni kekerasan. Bom bunuh diri menjadi metode yang sering dipakai oleh kelompok ini. Sementara itu, kelompok mutatharrifun nirkekerasan adalah mereka yang menghendaki Kembali ke kitab suci dalam pengertiannya yang paling letterlijk, harafiyah. Dalam hal pemahaman keagamaan, Indonesia sekarang ini tengah mengalami kenaikan tingkat ortodoksi dan ultraortodoksi di kalangan masyarakat luas. Berbagai hasil survei yang dilakukan oleh sejumlah Lembaga, misalnya Indonesia Muslim Report (2019), menyebutkan bahwa tingkat ortodoksi di Indonesia mencapai 25,5 persen, sementara itu kelompok ultra ortodoks mencapai 11,6 persen. Prosentase tersebut tentu saja sangat mencengangkan mengingat jumlah penduduk Muslim di negeri ini mencapai 207 juta orang. Belum lagi jika kita melihat kecenderungan munculnya berbagai Gerakan keagamaan yang mengusung ideologi jihad (kelompok jihadis), ideologitransnasional (khilafah), Gerakan keagamaan yang mengusung ujaran kebencian, intoleransi dan kekerasan, dan Gerakan-gerakan sejenis lainnya. Kelompok muda (milenial) merupakan kelompok usia yang paling rentan terhadap infiltrasi ideology radikalisme.

(2). Politik identitas. ${ }^{38}$ Tantangan kedua berasal dari politik identitas sebagai instrument politik yang menyatukan kelompok tertentu dan memecah kelompok massa lainnya dengan menggunakan isu-isu identitas etnik dan keagamaan. Politik identitas biasanya menguat hanya pada saat-saat diselenggarakannya demokrasi electoral seperti Pemilu dan Pemilukada. Pada dua kali pemilu presiden (2014 dan 2019), isu politik identitas menjadi media kampanye yang berdampak pada pembelahan sosial di kalanganpemilih di akar rumput.

Kubu pendukung Jokowi disebut oleh para pendukung kubu Prabowo sebagai kelompok "cebong", sementara kubu pendukung Jokowi menyebut kubu pendukung Prabowo sebagai "kampret". Sekalipun sebutan-sebutan semacam ini sudah relatif berkurang, namun residunya masih terasa di kalangan segelintir masyarakat. Politik identitas di kalangan masyarakat sempat mencapai titik kulminasinya pada aksi Bela Islam yang diselenggarakan pada tanggal 2 Desember 2016 (dikenal sebagai aksi “212”) dalam rangka menuntut ke meja hijau Gubernur (non-aktif) Basuki Tjahaja Purnama

38 "Majalah FORUM Forum Kerukunan Umat Beragama Jawa Timur." 
(Ahok) yang dianggap telah melecehkan Islam. Sekalipun pada mulanya bersifat insidentil dan ditujukan hanyau ntuk memenjarakan Ahok, aksi "212" terbukti ampuh sebagai senjata dalam rangka menghimpun sentiment keagamaan dari kalangan tertentu untuk melakukan tekanan politik kepada pemerintah. Setelah berhasil memenjarakan Ahok, mereka beberapa kali mengonsolidasikan kekuatannya pada saat penjemputan Habib Rizieq Syihab (HRS) sepulang dari pengasingannya selama lebih dari tiga tahun di Saudi Arabia. Aksi massa yang membuat macet Jakarta tersebut bahkan sempat menjadi biang penundaan pesawat akibat para calon penumpang terjebak kemacetan dalam perjalanan menuju bandara Soekarno-Hatta.

Pada intinya, politik identitas hanya hendak menegaskan kekuatan sebuah kelompok sosial berdasarkan afiliasi etnik atau keagamaan sebagai medium untuk menekan kelompok tertentu, terutama pemerintah. Ia tidak lebih dari sekadar "politik kerumunan" (politics of crowd) yang sengaja digerakkan oleh para tokoh elite-nya untuk menghimpun dan menggalang kekuatan massa untuk melakukan resistensi dan tekanan terhadap kebijakan politik pemerintah. Setiap individu yang berafiliasi dengan kelompok massa tertentu memanfaatkan identitas politik melalui kesamaan aspirasi politik dan keagamaan tertentu. Tujuannya adalah politik kekuasaan. Sementara itu, identitas keagamaan hanya berfungsi sebagai kendaraan saja.

(3). Era Media Sosial\& Post-truth, ${ }^{39}$ Penggalangan emosi dan sentimen keagamaan melalui politiki dentitas menjadi sesuatu yang mungkin terjadi berkat membuncahnya era digital sebagai buah dari revolusi industri 4.0. Era ini mendekonstruksi definisi kelompok dan interaksi sosial dari pengertiannya yang konvensional menuju pola komunikasi yang teratomisasi melalui media sosial. Manusia secara mudah terhubung satu sama lain melalui kanal-kanal media sosial seperti Facebook, whatsapp, Instagram, tweeter, telegram, dan lain sebagainya. Media sosial menjadi perekat kelompok sosial dengan identitas keagamaan yang sama, dan melemahkan kelompok sosial dengan identitas keagamaan yang berbeda. Media sosial berperan dalam menguatkan sentimen dan solidaritas in-group di dalam kelompok keagamaan yang sama (bonding), sembari melemahkan solidaritas out-group antar kelompok keagamaan yang berbeda (bridging).

39 "Majalah FORUM Forum Kerukunan Umat Beragama Jawa Timur."

Tribakti: Jurnal Pemikiran Keislaman

Volume 32, Nomor 1, Juli 2021 
Dalam banyak kasus, penggalangan sentimen SARA dilakukan melalui kanalkanal media sosialini. Era digital juga ditandai oleh permainan berita bohong yang dikelola sedemikian rupa sehingga terkesan seolah-olah menjadi kebenaran. Pengulangan dan gempuran bertubi-tubi berita bohong melalui kanal-kanal media sosial menjadi penopang utama era pasca kebenaran (post-truth). Kemenangan Donald Trump atas lawannya Hillary Clinton pada pemilu presiden AS tahun 2016 menandai dimulainya era pasca kebenaran ini. Kemenangan Trump banyak dibantu oleh beritaberita bohong yang dibombardir keruang publik oleh para buzzer professional untuk menggelembungkan basis dukungan suaranya dan menggembosi basis suara lawan politiknya. $^{40}$

Sekalipun banyak tantangan yang dihadapi dalam membumikan moderasi beragama di Indonesia, khsusnya Jawa Timur, tetapi masih ada peluang bagi FKUB untuk terus membumikan moderasi beragama di Jawa Timur, peluang ini terlihat dari beberapa faktor, pertama, faktor budaya ${ }^{41}$ secara keseluruhan masyarakat Jawa Timur mempunyai sikap tetrbuka, ramah, tepo sliro, tenggangrasa, santun dalam pergaulan, dan menggunakan tata karma dalam berkomunikasi, sehingga kerangka budaya yang sudah mendarah daging tersebut akan mempermudah penguatan moderasi beragama di masyarakat. ${ }^{42}$ Kedua, ikatan sebangsa dan setanah air, serta kesadaran sebagai mahluk sosial yang tidak dapat hidup sendiri dalam mengatasi kebutuhan hidup. Ketiga, hubungan sosial dan intensitas komunikasi antar tokoh lintas agama ${ }^{43}$ serta lintas budaya melalui berbagai media dan forum komunikasi sehingga terjadi proses pendekatan untuk lebih saling memahami dan menerima perbedaan antar kelompok keagamaan. ${ }^{44}$

Ke depan moderasi beragama nenjadi salah satu kunci dalam membangun bangsa yang didasari pada realitas heterogenitas masyarakatnya, seperti Indonesia, oleh karena

${ }^{40}$ Dalam kajian lain, Media sosial juga dapat berperan sebagai sarana untuk memperkuat hubungan antar pemuda lintas Agama, seperti dalam tulisan M. Thoriqul Huda dan Okta Filla, "Media Sosial sebagai Sarana Membangun Kerukunan Pada Komunitas Young Interfaith Peacemaker," Religi; Jurnal Studi Agama-agama 15, no. 1 (2019): 28-50; Jauhar Fuad, "Akar Sejarah Moderasi Islam Pada Nahdlotul Ulama," Tribakti; Jurnal Pem6ikiran Islam 31, no. 1 (2020):153-168.

${ }^{41}$ M.Thoriqul Huda dan Irma Khasanah, "Budaya Sebagai Perekat Hubungan Antar Umat Beragama di Suku Tengger,” SANGKeP; Jurnal Kajian Sosial Kegamaan 2, no. 2 (2019): 151-70. 114.

${ }^{42}$ Huda, "Strategi, Peluang dan Tantangan Membangun Kerukunan PemudaDi Era Milenial," 98-

${ }^{43}$ Salah satunya dapat kita lihat dari peran komisi hubungan antar umat beragama pada Gereja Katolik, baca dalam M. Thoriqul Huda dan Nur Hidayati, "Peran Komisi Hubungan Antar Umat Beragama Gereja Katoilk dalam Membangun Dialog," Religi; Jurnal Studi Agama-agama 14, no. 2 (2019): 194-216.

${ }^{44}$ Huda, "Strategi, Peluang dan Tantangan Membangun Kerukunan PemudaDi Era Milenial," 114. 
itu perlu support dari semua pihak dalam membumikan wawasan moderasi beragama, dari sekedar kerangka berfikir menjadi sikap gerak dalam kehidupan sehari-hari.

\section{Kesimpulan}

Upaya membumikan moderasi beragama mulai bergeliat dalam beberapa waktu tahun terahir ini, hal ini tidak lepas dari kondisi sosial-politik-keagamaan bangsa Indonesia yang terus diombang-ambing oleh isu keagamaan, saling mengkafirkan, saling menyalahkan, bahkan sudah tidak dapat dibedakan lagi mana persoalan politik dan mana persoalan agama, kedua isu bercampur sehingga semakin memperkeruh persoalan yang ada di masyarakat.

Melihat kondisi yang demikian, upaya membumikan moderasi beragama bagi pemeluk agama menjadi suatu keharusan, termasuk yang dilakukan oleh Forum Kerukunan Umat Beragama Jawa Timur, dimana moderasi beragama menjadi salah satu program yang harus dibumikan guna mendasari sikap katrakter kehidupan masyarakat, agar tercipta kehidupan yang rukun dan damai antar umat beragama.

Forum Kerukunan Umat Beragama provinsi Jawa Timur memiliki strategistrategi dalam membumikan moderasi beragama, serta berupaya memperluas peluang dalam membumikan moderasi beragama.

Kedepannya penelitian berkaitan dengan moderasi beragama harus lebih banyak digaungkan, terlebih bahwa Indonesia kaya dengan tradisi yang secara tidak langsung memperkuat program-program moderasi beragama di Indonesia.

\section{Daftar Pustaka}

Ardianto, Dedy. Wawancara dengan Pemuda FKUB, t.t.

Bakar, Abu. "Theologi Fundamentalisme", Toleransi; Media Komunikasi Umat Beragama" 6, no. 2 (t.t.): 2014.

Burhani, Ahmad Najib. "Pluralism, Liberalism and Islamism: Religious Outlook of the Muhammadiyah Islamic Movement in Indonesia, M.A." Faculty of Humanities, University of Manchster, 2007.

Direktur Jenderal Pendidikan Islam. "Keputusan Direktur Jenderal Pendidikan Islam Nomor 897 Tahun 2021 Tentang Petunjuk Teknis Rumah Moderasi Beragama." Http://diktis.kemenag.go.id/v1/public/files/ec92fa8e02bc0f378c961ae5729908 75.Edaran\%20Juknis\%20Rumah\%20Moderasi\%20Beragama\%20(12\%20Mare t\%202021).pdf, t.t.

Ediyono, Suryo. "Coping with Fundamentalism in a Tolerant Country, International Journal of Multicultural and Multireligious Undertansding" 6, no. 1 (2019). 
Fahri, Mohamad. “Moderasi Beragama di Indonesia.” Intizar 25, no. 2 (2019).

Forum Kerukunan Umat Beragama Provinsi Jawa Timur. Sewindu. Surabaya: FKUB Jatim, 2014.

Fuad, Jauhar. "Akar Sejarah Moderasi Islam Pada Nahdlotul Ulama." Tribakti; Jurnal Pem6ikiran Islam 31, no. 1 (2020).

Haris, Ach. Faid, dan Marwini. "Pelarangan Aktifitas Jamaat Ahmadiyah Indonesia Prespektif Hukum dan HAM ((Mengkaji Legalitas Sk Gubernur Jawa Timur Nomor 188/94/Kpts/013/2011)." Al Mazahib; Jurnal Pemikiran Hukum 1, no. 2 (2012).

Hasan, Farid. "Model Pembacaan Kontekstual Nasr Hamid Abu Zayd Terhadap Teks Suci Keagamaan (Al Qur'an).” Jurnal Ilmiah Citra Ilmu 16, no. 31 (2020).

Hefni, Wildan. "Studi Pengarusutamaan Moderasi Beragama di Perguruan Tinggi Keagamaan Islam Negeri.” Jurnal BIMAS Islam 13, no. 1 (2020).

Hidayat, Komaruddin. Agama untuk Peradaban: Membumikan Etos Agama dalam Kehidupan. Komaruddin Hidayat: Alvabet, 2019.

Hilmy, Masdar. "Whiter Indonesia's Islamic Moderatism,? A Reexamination on the moderate Vision of Muhammadiyahand NU." 71 (2013).

Huda, M Thoriqul. "Strategi, Peluang dan Tantangan Membangun Kerukunan PemudaDi Era Milenial.” Satya Widya 3, no. 2 (2020): 19.

Huda, M. Thoriqul, dan Okta Filla. "Media Sosial sebagai Sarana Membangun Kerukunan Pada Komunitas Young Interfaith Peacemaker." Religi; Jurnal Studi Agama-agama 15, no. 1 (2019).

Huda, M. Thoriqul, dan Nur Hidayati. "Peran Komisi Hubungan Antar Umat Beragama Gereja Katoilk dalam Membangun Dialog." Religi; Jurnal Studi Agama-agama 14, no. 2 (2019).

Huda, M.Thoriqul, dan Irma Khasanah. "Budaya Sebagai Perekat Hubungan Antar Umat Beragama di Suku Tengger.” SANGKeP; Jurnal Kajian Sosial Kegamaan 2, no. 2 (2019).

Ida, Rachmah, dan Laurentius Dyson. "Konflik Sunni-Syiah dan dampaknya terhadap komunikasi intra-religius pada komunitas di Sampang-Madura." Masyarakat, Kebudayaan dan Politik 28, no. 1 (1 Januari 2015): 33. https://doi.org/10.20473/mkp.V28I12015.33-49.

Kemenag RI. Moderasi Beragama. Kementerian Agama, 2019.

"Keputusan Gubernur Jawa Timur Nomor 188/217 /KPTS/013/2015 Tentang Forum Kerukunan Umat Beragama (FKUB) Provinsi Jawa Timur Tahun 2015." Http://arsipjdih.jatimprov.go.id/upload/741/KEPGUB.NOMOR_217_.TAHU N_2015_TENTANG_FORUM_KERUKUNAN_UMAT_BERĀGAM̄MAPRO VINSI_JAWA_TIMUR_TAHUN_2015_.pdf, t.t.

“Majalah FORUM Forum Kerukunan Umat Beragama Jawa Timur,” 2021.

Masyhudi, Tamhid. Wawancara dengan Sekertaris FKUB, t.t. 
Miftahuddin. "Islam Moderat dalam Konteks Indonesia dalam Prespektif Historis." Jurnal Mozaik V, no. 1 (2010).

Mooduto, Masrun. "Identitas Etnik Kerukunan Pengawal Imam Bonjol di Desa Lotta Kabupaten Minahasa," 2016, 9.

Mulyadi, Mohammad. "Membangun NKRI dengan Multikulturalisme," t.t., 4.

Muslim, Asrul. "Interaksi Sosial dalam Masyarakat Multiatnis." Jurnal Diskursus Islam 1 , no. 3 (2013).

Muttaqien, Ahmad. "Spiritualitas Agama Lokal (Studi Ajaran Sunda Wiwitan aliran Madrais di Cigugur Kuningan Jawabarat)," t.t., 14.

Nurdin, Ali. "Model Moderasi Beragama Berbasis Pesantren Salaf." ISLAMICA; Jurnal Studi Keislaman 14, no. 1 (2019).

"Provinsi Jawa Timur Dalam Angka," 2012.

Pusat Bahasa Departemen Pendidikan Nasional. Kamus Bahasa Indonesia. Jakarta: Pusat Bahasa, 2008.

Subakir, Ahmad, dan Ahmad Khoirul Mustamir. "Gerakan Moderasi Islam dalam Prespektif Deteksi Dini; Studi Gerakan Pemuda Ansor Kota Kediri." Tribakti; Jurnal Pemikiran Islam 31, no. 2 (2020).

Suktiningsih, Wiya, dan Hilda Hastuti. "Situasi Diglosia Pada Penutur Bahasa Bali di Kota Mataram Nusa Tenggara Barat" 6, no. 1 (2019): 18.

Sutanto, Ayu, dan Setya Yowono Sudikan. Pendekatan Kebudayaan dalam Pembangunan Provinsi Jawa Timur, 2004.

Syarif, Hamid. Wawancara dengan Ketua FKUB Jawa Timur, t.t.

Widianingsih. "Demokrasi dan Pemilu di Indonesia: Suatu Tinjauan dari Aspek Sejarah dan Sosiologi Politik.” Jurnal Signal 5, no. 2 (2017). 


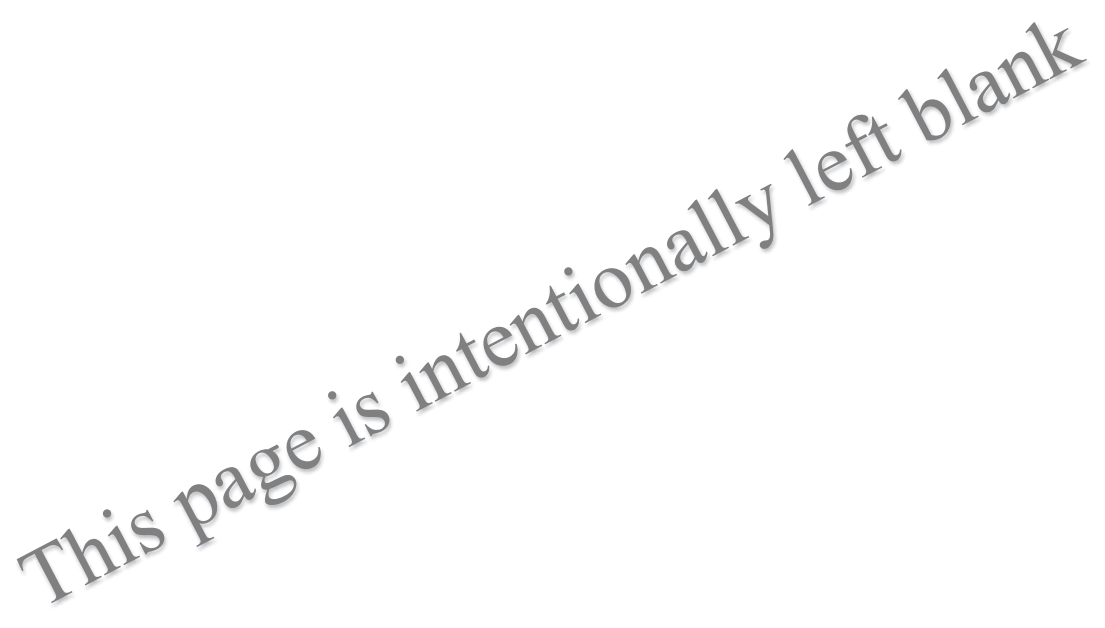

